\title{
STILISTIKA DAN NILAI PENDIDIKAN KARAKTER NOVEL SEORANG LAKI-LAKI YANG KELUAR DARI RUMAH KARYA PUTHUT EA
}

\author{
Prarasto Miftahurrisqi, Suyitno, Yant Mujiyanto \\ Universitas Sebelas Maret \\ Surel: prarastonasionalis@ @student.uns.ac.id
}

\begin{abstract}
This research aims to describe the use of diction, the figure of speech, the use of image andcharacter education valuesin novel Seorang Laki-Laki Yang Keluar Dari Rumah by Puthut EA. This research employed descriptive qualitative approach with content analysis method. The data of research was contained in novel Seorang Laki-Laki Yang Keluar Dari Rumah and the result of interview with some informants. Technique of collecting data used was library and interview techniques. In this study, the author employed flow model of analysis.The results of research were as follows. Firstly, diction used in novel Seorang Laki-Laki Yang Keluar Dari Rumah consisted of six types. Secondly, there were four figure of speeches used in novel Seorang Laki-Laki Yang Keluar Dari Rumah. Ellipsis as the part of linking figure of speech is used most widely by author. Thirdly, the image used in novel Laki-Laki Yang Keluar Dari Rumah consisted of six types visual images were used most widely. Fourthly, there were ten character education values in novel Seorang Laki-Laki Yang Keluar Dari Rumah. Curiosity education character value was the one used most dominantly.
\end{abstract}

Keywords: diction, figure of speech, image, character education

\begin{abstract}
Abstrak:Penelitian ini bertujuan untuk mendeskripsikan penggunaan diksi, gaya bahasa citraan dan nilai-nilai pendidikan karakter dalam novel Seorang Laki-Laki Yang Keluar Dari Rumah karya Puthut EA. Penelitian ini menggunakan pendekatan deskriptif kualitatif dengan metode analisis isi. Data penelitian ini terdapat dalam novel Seorang Laki-Laki Yang Keluar Dari Rumah dan hasil wawancara dengan beberapa informan. Teknik pengambilan sampel yang digunakan dalam penelitian ini adalah purposive sampling.Teknik pengumpulan data dalam penelitian ini menggunakan teknik pustaka dan teknik wawancara dengan model analisis mengalir (flow model of analysis). Berdasarkan hasil penelitian dapat disimpulkan bahwa (1) diksi yang digunakan dalam novel Seorang Laki-Laki Yang Keluar Dari Rumah terdapat enam jenis dan Kata serapan merupakan jenis diksi yang paling banyakdigunakan; (2) gaya bahasa yang digunakan dalam novel Seorang Laki-Laki Yang Keluar Dari Rumah terdapat empat jenis dan elipsis sebagai bagian dari gaya bahasa pertautan paling banyak digunakan; (3) citraan yang digunakan dalam novel Seorang Laki-Laki Yang Keluar Dari Rumah terdapat enam jenis dan citraan penglihatan merupakan jenis citraan yang paling banyak digunakan; (4) nilai pendidikan karakter dalam novel Seorang Laki-Laki Yang Keluar Dari Rumah terdapat sepuluh nilai dan nilai pendidikan karakter rasa ingin tahu yang paling banyak mendominasi.
\end{abstract}

Kata Kunci: diksi, gaya bahasa, citraan dan pendidikan karakter.

\section{PENDAHULUAN}

Karya sastra merupakan karya imajinatif dengan segala sesuatunya tersusun dari kata-kata sehingga membentuk tulisan yang memiliki beragam 
makna. Menurut Al-Ma ${ }^{e e}$ ruf (2010: 57) bahwa karya sastra umumnya sebagai karya seni yang memiliki ekspresi pengarang tentang hasil refleksinya terhadap kehidupan dengan berlatarkan bahasa. Namun, Ratna (2015: 299) menyatakan bahwa karya sastra adalah sebagai sistem komunikasi dimana setiap unit wacana berhubungan dan dapat dihubungkan dengan wacana lain bahkan dari semestaan yang lain. Senada dengan Wellek \& Werren, (2014: 3) yang menyatakan bahwa cara lain untuk memberikansebuah definisi sastra adalah membatasinya pada "mahakarya", yaitu buku-buku yang dianggap menonjol dengan bentuk dan ekspresi kesastraannya. Fungsi sastra atau karya sastra yakni dulce et utile, „menyenangkan dan berguna ${ }^{e e}$ seperti yang telah tertuang dalam rumusan estetika Yunani, Horace (dalam Wellek \& Warren, 2014: 23). Oleh karena itu, novel sebagai salah satu karya sastra dapat mengemukakan sesuatu dengan bebas, menyajikan cerita secara rincidan lebih banyak melibatkan permasalahan yang kompleks.

Menurut Suwandi (2013: 118) bahwa kata-kata yang seringkali dipergunakan dalam karya sastra jelas mengandung makna stilistika karena bisa menimbulkan suatu kesan mulai dari haru hingga jengkel bagi setiap pembacanya. Keraf (2006: 88) juga menjelaskan bahwa kata adalah rangkaian bunyi atau simbol tertulis yang menyebabkan orang berpikir tentang suatu hal dan makna sebuah kata pada dasarnya diperoleh karena persetujuan informal antar kelompok untuk meyatakan hal atau barang tertentu melalui rangkaian bunyi tertentu.Dalam memilih kata, biasanya penyair maupun penulis akan memperhitungkan efek yang ditimbulkan oleh perkataan tersebut.Kata-kata yang dipilih hendaknya bersifat puitis, yang memiliki efek keindahan, bunyinya indah dan memiliki keharmonisan dengan kata-kata lainnya (Kosasih, 2012: 97). Maka daripada itu Al-Maeruf (2010: 94-126) membagi pilihan kata atau diksi yang biasa digunakan oleh pengarang, penyair maupun penulis karya sastra yakni: (1) Kata Konotatif; (2) Kata Konkret; (3) Kata Serapan; (4) Kata Sapaan; (5) Kata Vulgar;

(6) Kata dengan Realitas Objek Alam. Pembagian kata-kata tersebut sangat berguna dalam menulis sebuah karya sastra bagi penulis maupun penyair dan apresiasi terhadap karya sastra bagi pembacanya. 
Menurut Abramsbahwa stile atau biasa disebut dengan gaya bahasa adalah cara pengucapan bahasa dalam prosa atau bagaimana seorang pengarang mengungkapkan sesuatu yang akan dikemukakannya (Nurgiyantoro, 2013: 369). Tarigan (2013: 5) juga berpendapat bahwa gaya bahasa adalah mengungkapkan pikiran melalui bahasa secara khas yang memperlihatkan jiwa dan kepribadian penulis. Menurut Nurgiyantoro (2013: 370) bahwa gaya bahasa pada hakikatnya merupakan teknik pemilihan ungkapan kebahasaan yang dapat mewakili sesuatu yang akan diungkapkan dan sekaligus mencapai efek keindahan.Semua gaya dalam hubungan ini gaya bahasa sastra, khususnya karya sastra yang berhasil adalah artifisial, diciptakan dengan sengaja (Ratna, 2016: 6).Karya sastra dalam bentuk bahasa sebagai naskah itu pun dapat digunakan dalam kaitannya dengan pengkajian gaya bahasa. Pada akhirnya, Tarigan (2013: 5) membagi kelompok gaya bahasa yang sering dipergunakan yakni : (1) Gaya Bahasa Perbandingan; (2) Gaya Bahasa Pertentangan; (3) Gaya Bahasa Pertautan; (4) Gaya Bahasa Perulangan.Masing-masing jenis gaya bahasa tersebut memiliki beberapa subjenis yang saling melengkapi satu sama lain.

Dalam dunia kesastraan, dikenal adanya istilah citra (image) dan citraan (imagery) yang keduanya menunjuk pada reporduksi mental. Menurut Nurgiyantoro (2013: 411) bahwa citraan merupakan suatu gaya penuturan yang banyak dimanfaatkan dalam penulisan karya sastra. Artinya, dapat dipergunakan untuk mengonkretkan pengungkapan gagasan yang sebenarnya asbtrak melalui kata-kata dan ungkapan yang mudah membangkitkan tanggapan imajinasi pembacanya.Citraan memberikan kemudahan bagi pembaca. Ketepatan pemilihan bentuk citraan tertentu yang sesuai berarti pula ketepatan bentuk pengungkapan bahasa dan ketepatan gaya bahasa. Wellek \& Warren (2014: 216) menjelaskan bahwa pencitraan sebenarnya merupakan topik yang termasuk dalam bidang psikologi dan studi sastra karena ahli-ahli psikologi maupun ahli-ahli estetika menyusun berbagai macam jenis pencitraan ke dalam karya sastra. Citraan dalam karya sastra tersebut secara umum terbagi menjadi enam jenis yakni : (1) Citraan Penglihatan;(2) Citraan Pendengaran, (3) Citraan Gerak, (4) Citraan Perabaan; (5) Citraan Penciuman dan (6) Citraan Pengecapan. Salah satu sarana dalam 
mewujudkan citraan yang dilakukan oleh pengarang ialah dengan menggunakan gaya bahasa (Sutejo, 2010 : 26).Dengan demikian, gaya citraan dapat muncul melalui kalimat dengan gaya bahasa dan keduanya dapat bergabung dalam satu kalimat.

Nurgiyantoro (2013: 434)menjelaskan bahwa karya sastra memiliki peran sebagai salah satu alat pendidikan yang seharusnya dimanfaatkan dalam dunia pendidikan. Ratna (2014: 234)menjelaskan lebih lanjut bahwa memanfaatkan karya sastra dalam rangka menopang pendidikan karakter berarti menghargai, melestarikan warisan nenek moyang sekaligus membatasi pengaruh budaya asing sebab segala sesuatu yang terkandung di dalamnya karena kualitas pendidikan karakter yang sesungguhnya adalah nilai-nilai seperti diturunkan melalui ketaksadaran kolektif, memori masa lampau yang sudah tertanam sejak ratusan bahkan ribuan tahun. Lebih jauh lagi, Darweesh \& Ghayadh (2016) menyatakan bahwa salah satu peran dasar dari sebuah karakter dalam karya sastra adalah membimbing pembaca, memahami plot dan mempertimbangkan tema.Salah satu manfaat dari pendidikan karakter yang berkualitas menurut Pala (2011) adalah menciptakan budaya berkarakter terpadu yang mendukung dan menantang siswa dan orang dewasa untuk mencapai cita-cita. Jadi, dapat disimpulkan bahwa teks kesastraan seperti novel diyakini mengandung unsur moral dan nilai-nilai karakter yang dapat dijadikan bahan baku pendidikan karakter.

Pada penelitian ini, penulis akan mengkaji tentang sebuah novel yang berjudul Seorang Laki-Laki Yang Keluar Dari Rumah. Penulis karya novel tersebut adalah Puthut EA. Ia adalah seorang novelis sekaligus penulis naskah drama dan beberapa karya-karyanya termuat secara online di website yang ia pimpin saat ini yakni Mojok.Co. Novel Seorang Laki-Laki Yang Keluar Dari Rumah menceritakan kisah dengan permasalahan yang kompleksitas dan memiliki alur cerita yang unik bahkan berbeda dari penulis-penulis novel pada umumnya. Penelitian ini bertujuan mendeskripsikan bagaimana stilistika dalam penggunaan diksi, gaya bahasa dan citraan karya sastra berbentuk novel dengan judul Seorang Laki-Laki Yang Keluar Dari Rumah. Novel ini memiliki banyak 
sekali pembelajaran berkarakter atau pesan-pesan yang diselipkan oleh penulis baik itu secara moral, etika, budaya bahkan agama dalam alur ceritanya sehingga terlihat seperti yang ada di kehidupan sehari-hari.

\section{METODE PENELITIAN}

Penelitian ini menggunakan pendekatan deskriptif kualitatif dengan metode analisis isi.Menurut Sutopo (2006 : 40) bahwa dalam penelitian kualitatif deskriptif lebih menekankan catatan dengan deskripsi kalimat yang rinci, lengkap dan mendalam, yang menggambarkan situasi sebenarnya guna mendukung penyajian data. Ratna (2015 : 49) menyatakan bahwa metode analisis isi adalah metode yang dilakukan atas dasar penafsiran pada arti maupun makna dalam dokumen-dokumen yang padat isi seperti misalnya gaya tulisan seorang pengarang.

Data dan sumber data dalam penelitian ini terdapat dalam novel Seorang Laki-Laki Yang Keluar Dari Rumah karya Puthut EA dan hasil wawancara dengan beberapa informan. Teknik pengambilan sampel yang digunakan dalam penelitian ini adalah purposive sampling. Sutopo (2006 : 58) berpendapat bahwa pilihan sampel dalam penelitian kualitatif diarahkan pada sumber data yang dipandang memiliki data yang penting dan berkaitan dengan permasalahan yang sedang diteliti.

Teknik pengumpulan data dalam penelitian ini menggunakan teknik pustaka dan teknik wawancara.Triangulasi yang digunakan peneliti adalah triangulasi teori dan triangulasi sumber data.Dalam penelitian ini, peneliti menggunakan model analisis mengalir (flow model of analysis) yang telah dikemukan oleh Miles \& Huberman (Sutopo, 2006 : 114-115; Ratna, 2010 : 310) sebagai teknik analisis data.

\section{HASIL PENELITIAN DAN PEMBAHASAN}

Data penelitian ini menggunakan pendekatan stilistika yang meliputi diksi, gaya bahasa dan citraan. Selain itu, penelitian ini juga mengkaji nilai-nilai pendidikan karakter yang terdapat dalam novel Seorang Laki-Laki Yang Keluar 
Dari Rumah. Penyajian hasil dan pembahasan data penelitian ini dalam bentuk analisis secara deskriptif, tabel maupun gambar. Berikut adalah hasil analisis data secara deskriptif beserta pembahasannya yang telah diperoleh dari novel Seorang Laki-Laki Yang Keluar Dari Rumah karya Puthut EA.

Penggunaan Diksi dalam Novel Seorang Laki-Laki Yang Keluar Dari Rumah Berikut akan dianalisis diksi dalam novel Seorang Laki-Laki Yang

Keluar Dari Rumah karya Puthut EA yang meliputi enam jenis meliputi kata konotatif, kata konkret, kata serapan, kata sapaan khas, kata vulgar, kata realitas objek alam.

\section{Kata Konotatif}

Membelah Yogya yang bukan hanya sedang terik, tapi juga macet. (SLLYKDR: 45)

Pada kutipan cerita tersebut, pengarang menggunakan kata konotatif yakni kata membelah. Kata membelah bisa diartikan sebagai kata menelusuri karena makna dari kata membelah dalam kalimat tersebut adalah melakukan perjalanan di suatu tempat.

\section{Kata Konkret}

Lalu aku pergi setelah memberikan uang dua puluh ribu kepada perempuan itu. (SLLYKDR:2)

Pada kutipan cerita tersebut, pengarang menggunakan kata konkret yakni bagian kalimat uang dua puluh ribu. Hal tersebut sangat jelas dipahami pembaca karena uang sebagai alat pembayaran yang sah dan sesuai dengan jumlah nominal dalam memanfaatkan barang maupun jasa.

\section{Kata Serapan}

Mereka satu kelas sejak playgroup hingga sekarang di TK. (SLLYKDR: 8)

Pada kutipan cerita tersebut, pengarang menggunakan kata serapan dari bahasa Inggris yakni kata playgroup. Kata playgroup diartikan dalam bahasa Indonesia sebagai frasa kelompok bermain. Penggunaan kata playgroup 
menunjukkan ekspresi pengarang yang memiliki kemampuan intelektual baik dalam memahami pendidikan.

Kata Sapaan Khas

Tepat di saat itu, Aam alias Cak Amrullah keluar membawa secangkir kopi. (SLLYKDR: 110)

Pada kutipan cerita tersebut, pengarang menggunakan kata sapaan khas yakni kata Aam dan frasa Cak Aam. Penggunaan kata Aam merupakan sebutan atau panggilan nama dari salah satu tokoh dalm cerita yakni Amrullah. Penggunaan kata Cak oleh pengarang sebagai bentuk sapaan penghormatan bagi orang atau masyarakat sosial di Jawa Timur dan setara dengan kata sapaan Mas yang paling umum digunakan di sekitaran Jawa Tengah maupun Yogyakarta.

Kata Vulgar

Aku harus memberikan tas yang, bangsat betul, sejak kapan membawanya saja aku tak tahu, apalagi isinya. (SLLYKDR: 5)

Pada kutipan cerita tersebut, pengarang menggunakan kata vulgar yakni frasa bangsat betul. Kata bangsat biasanya digunakan untuk mengumpat atau berbicara buruk kepada seseorang sehingga kurang pantas atau tabu. Penggunaan frasa bangsat betul oleh pengarang dalam cerita tersebut menunjukkan ekpresi ketidakpercayaan suatu hal yang sebelumnya tidak pernah diduga atau semacam kemustahilan oleh tokoh cerita.

\section{Kata Realitas Objek Alam}

Tiba-tiba mobil masuk ke jalanan dengan kanan-kiri sawah. Gelap. Hanya ada cahaya mobilku. Dan tiba-tiba pula mobil seperti memasuki sebuah kota yang kukenal. Kemudian masuk lagi ke jalanan dengan pemandangan penuh ladang tebu. Balik lagi ke jalanan kota yang kukenal. Bedanya bukan kota yang piruk melainkan lengang. (SLLYKDR:2)

Pada kutipan cerita tersebut, pengarang menggunakan kata realitas objek alam yakni kata sawah dan frasa ladang tebu. Penggunaan kata sawah dan frasa ladang tebu oleh pengarang dalam cerita tersebut menunjukkan kejelasan latar cerita sehingga pembaca dapat memahami alur cerita dengan mudah. 
Berdasarkan data hasil penelitian, diketahui bahwa terdapat enam jenis diksi yang digunakan dalam novel Seorang Laki-Laki Yang Keluar Dari Rumah karya Puthut EA. Keenam diksi tersebut meliputi: (1) kata konotatif, (2) kata konkret, (3) kata serapan, (4) kata sapaan khas, (5) kata vulgar, (6) kata realitas objek alam. Untuk mendapatkan informasi yang lebih jelas, perhatikan tabel 1 berikut ini.

\begin{tabular}{clc}
\hline No & \multicolumn{1}{c}{ Diksi } & Frekuensi Penggunaan \\
\hline 1 & Vulgar & 14 \\
\hline 2 & Realitas Objek Alam & 48 \\
\hline 3 & Sapaan Khas & 61 \\
\hline 4 & Konotatif & 73 \\
\hline 5 & Konkret & 292 \\
\hline 6 & Serapan & 313 \\
\hline
\end{tabular}

Tabel 1 Penggunaan Diksi dalam Novel Seorang Laki-Laki Yang Keluar

\section{Dari Rumah}

Dari keenam jenis diksi tersebut, kata serapan merupakan jenis diksi yang paling banyak digunakan dengan jumlah sebanyak 313 temuan dengan presentase sebesar 39,1\% dari 801 data. Berbanding terbalik dengan pilihan kata vulgar yang paling sedikit digunakan jumlahnya hanya 14 temuan dengan presentase hanya 1,7\% saja. Penggunaan kata serapan sebagai diksi paling banyak digunakan dalam novel merupakan bentuk efektif, sekaligus mewakili gagasan yang ingin disampaikan pengarang kepada pembaca.

Kata serapan digunakan oleh pengarang mewakili gagasan yang ingin disampaikan pengarang kepada pembaca melalui kosakata dari bahasa tradisional maupun bahasa asing. Selain itu, penggunaan kosa kata serapan teruatama dari bahasa asing terasa efektif dalam mewakili gagasan yang diinginkan oleh pengarang kepada pembacanya. Dalam hal ini, pengarang menggunakan 3 bahasa yang paling sering ditemukan yakni bahasa tradisional (bahasa Jawa) dan bahasa asing (Inggris dan Arab). Hal ini sejalan dengan pendapat Al-Maeruf (2010: 106107) yang menyatakan bahwa dengan menggunakan kata-kata serapan akan terkesan lebih plastis daripada menggunakan kata lain. Artinya, pengarang dalam hal ini memilih kata serapan untuk mempermudah penyampaian gagasan cerita kepada pembaca sehingga dapat dipahami. 
Penggunaan Gaya Bahasa dalam Novel Seorang Laki-Laki Yang Keluar Dari Rumah Karya Puthut EA.

Berikut akan dianalisis gaya bahasa dalam novel Seorang Laki-Laki Yang Keluar Dari Rumahkarya Puthut EA yang meliputi empat jenis dengan berbagai macam sub jenis pada tiap jenis meliputi gaya bahasa perbandingan meliputi: simile, metafora, antisipasi, koreksi; gaya bahasa pertentangan meliputi: hiperbola, apofasisi, sarkasme, klimaks, oksimoron; gaya bahasa pertautan meliputi: metonimia, erotesis, elipsis, sinekdoke, asindeton, polisindeton; gaya bahasa perulangan meliputi: anafora, epizeukis, anadiplosis, epistrofa.

Simile

Aku bisa menyaksikannya menarik dan mengembuskan napas. Tenang. Seperti laut di musim teduh. (SLLYKDR: 136)

Pada kutipan cerita tersebut, pengarang menggunakan gaya bahasa perbandingan jenis simile yakni kalimat Seperti laut di musim teduh.Interpretasi dari kutipan tersebut adalah menyamakan ketenangan tokoh cerita sebagaimana kondisi air laut yang tenang di musim kemarau.

Metafora

Sebagian sejarah kita tertumpuk di Belanda, dan untuk membantu mendirikan bangunan sejarah itu, salah satu tiang yang harus dipancungkan adalah membaca dokumen-dokumen tersebut. (SLLYKDR: 47)

Pada kutipan cerita tersebut, pengarang menggunakan gaya bahasa perbandingan jenis metafora yakni bagian tiang yang harus dipancungkan. Interpretasi dari kutipan tersebut adalah menyamakan suatu hal penting yang harus dilakukan sebagaimana tiang yang ditegakkan.

Antisipasi

Pukul dua belas malam nanti, di sebuah kompleks perumahan dosen UGM di daerah Bulaksumur, akan ada diskusi (SLLYKDR: 163)

Pada kutipan cerita tersebut, pengarang menggunakan gaya bahasa perbandingan jenis antisipasi yakni bagian Pukul dua belas malam nanti. Interpretasi dari kutipan tersebut adalah penggunaan waktu yang menunjukkan 
pukul 00.00 atau dua belas malam sebagai antisipasi yang akan dialami oleh tokoh cerita.

Koreksi

Lalu dia berkali mendesah. Oh, bukan. Berzikir. (SLLYKDR: 261)

Pada kutipan cerita tersebut, pengarang menggunakan gaya bahasa perbandingan jenis koreksi. Interpretasi dari kutipan tersebut adalah awal kalimat Lalu dia berkali mendesah mendapatkan bentuk koreksi yang dilakukan oleh tokoh cerita sendiri menjadi kata Berzikir dengan menggunakan kata bukan.

\section{Hiperbola}

Walaupun sampai langit runtuh aku yakin tak akan bisa mengerti. (SLLYKDR: 23)

Pada kutipan cerita tersebut, pengarang menggunakan gaya bahasa pertentangan jenis hiperbola Interpretasi dari kutipan tersebut adalah penggunaan frasa langit runtuh memberikan kesan berlebihan dalam penyampaian ide cerita kepada pembaca.

Apofasisi

Pukul dua belas malam nanti, di sebuah kompleks perumahan dosen UGM di daerah Bulaksumur, akan ada diskusi. Ah, kata diskusi tak terlalu tepat, mungkin mengobrol. (SLLYKDR: 163)

Pada kutipan cerita tersebut, pengarang menggunakan gaya bahasa pertentangan jenis apofasisi. Interpretasi dari kutipan tersebut adalah penggunaan kata ah sebagai bentuk apofasisi karena memiliki kesan meremehkan dan ditambah dengan bagian kalimat kata diskusi tak terlalu tepat yang terlihat menyangkal atau mengingkari penjelasan sebelumnya menjadi anggapan dari tokoh cerita itu sendiri yakni pada frasa mungkinmengobrol.

\section{Sarkasme}

“Diam kamu, asu!" (SLLYKDR: 217)

Pada kutipan cerita tersebut, pengarang menggunakan gaya bahasa pertentangan jenis sarkasme. Interpretasi dari kutipan tersebut adalah penggunaan kata asu yang berasal dari kosakata bahasa Jawa yaitu untuk menyebut nama 
hewan anjing sebagai bentuk sarkasme karena tokoh cerita telah mengumpat dan menyebut secara tidak sopan lawan bicaranya.

Klimaks

Pelayan datang, membawa segelas air es, Rusli mengaduk minumannya sebentar, tapi kemudian dia mengambil bongkahan es dengan sendoknya dan dikeletusi. (SLLYKDR:65)

Pada kutipan cerita tersebut, pengarang menggunakan gaya bahasa pertentangan jenis klimaks. Interpretasi dari kutipan tersebut adalah adanya kata kerja seperti kata membawa, kata mengaduk, kata mengambil dan kata dikeletusi yang dapat menunjukkan sebuah peningkatan atau pemuncakan dari suatu kejadian yang dialami oleh tokoh cerita.

Oksimoron

Suasana terasa sunyi walaupun lalu-lalang kendaraan sangat ramai. (SLLYKDR:102)

Pada kutipan cerita tersebut, pengarang menggunakan gaya bahasa pertentangan jenis oksimoron. Interpretasi dari kutipan tersebut adalah penggunaan kata sunyi dan kata ramai menjadi satu bagian konstruksi kalimat sehingga menimbulkan pertentangan atau berlawanan suasana yang dirasakan oleh tokoh cerita.

\section{Metonimia}

"Mas ke tempat cukur rambut saja. Aku beli Tolak Angin dulu." (SLLYKDR: 37)

Pada kutipan cerita tersebut, pengarang menggunakan gaya bahasa pertautan jenis metonimia. Interpretasi dari kutipan tersebut adalah penggunaan frasa Tolak Angin sebagai objek yang ditautkan dengan nama salah satu merk dagang obat herbal tradisional asli Indonesia untuk mengobati masuk angin.

Erotesis

Bagaimana rasanya berada tepat di tengah orang-orang yang sedang baku tembak? (SLLYKDR: 199)

Pada kutipan cerita tersebut, pengarang menggunakan gaya bahasa pertautan jenis erotesis. Interpretasi dari kutipan tersebut adalah pengarang 
menggunakan kata bagaimana sebagai bentuk pertanyaan yang sebenarnya untuk penekanan cerita.

Elipsis

“Aku suka belajar ... suka mencari guru.” (SLLYKDR: 128)

Pada kutipan cerita tersebut, pengarang menggunakan gaya bahasa pertautan jenis elipsis. Interpretasi dari kutipan tersebut adalah adanya penghilangan di tengah-tengah kalimat yang disebut anakoluton. Hal tersebut memberikan kesan kalimat yang rumpang sehingga pembaca harus menafsirkan sendiri kalimat tersebut.

Sinekdoke (Pars Pro Toto)

Sepintas dari bahasa mereka, tampaknya rombongan kecil dari Jerman. (SLLYKDR:306)

Pada kutipan cerita tersebut, pengarang menggunakan gaya bahasa pertautan jenis sinekdoke pars pro toto. Interpretasi dari kutipan tersebut adalah bagian yang menyatakan sebagian terletak pada frasa rombongan kecil sedangkan untuk yang menyatakan keseluruhan terletak pada kata Jerman.

Sinekdoke (Totem Pro Parte)

"Australia juga punya kepentingan dengan tambang-tambang di situ." (SLLYKDR:134)

Pada kutipan cerita tersebut, pengarang menggunakan gaya bahasa pertautan jenis sinekdoke totem pro parte. Interpretasi dari kutipan tersebut adalah bagian yang menyatakan keseluruhan terletak pada kata Australia dan bagian yang menyatakan sebagian terletak pada frasa tambang-tambang.

Asindeton

Laki-laki di depanku itu mengedip pelan, napasnya sangat teratur, wajahnya tenang. (SLLYKDR: 74)

Pada kutipan cerita tersebut, pengarang menggunakan gaya bahasa pertautan jenis asindeton. Interpretasi dari kutipan tersebut adalah adanya penggunaan tanda koma (,) sebagai tanda hubung dan tidak ada penggunaan kata penghubung. 


\section{Polisindeton}

Aku menahan tangannya lalu mengambil poci porselen dan mengisi sampai setengah, kemudian kuulurkan cangkir itu kepadanya. (SLLYKDR: 7)

Pada kutipan cerita tersebut, pengarang menggunakan gaya bahasa pertautan jenis polisindeton. Interpretasi dari kutipan tersebut adalah adanya penggunaan kata penghubung seperti lalu, dan, kemudian .

Anafora

Bayang-bayang. Bayang-bayang masa lalu. Bayang-bayang yang kukubur bersama sebagian kisah-kisah masa lalu. (SLLYKDR: 334)

Pada kutipan cerita dalam data (3), pengarang menggunakan gaya bahasa perbandingan perulangan jenis anafora. Interpretasi dari kutipan tersebut adalah adanya penggunaan frasa Bayang-bayang pada awal kalimat.

Epizeukis

Orang-orang yang gemar memotret mencari tempat terbaik untuk memotret matahari terbit. (SLLYKDR: 306)

Pada kutipan cerita dalam data (3), pengarang menggunakan gaya bahasa perulangan jenis epizeukis. Interpretasi dari kutipan tersebut adalah pengulangan pada kata memotret dalam satu kalimat sebagai penekanan cerita.

Anadiplosis

Kulirik Om Tan yang juga diam. Diam yang tidak tenang sekaligus tidak gugup. (SLLYKDR: 215)

Pada kutipan cerita dalam data (3), pengarang menggunakan gaya bahasa perulangan jenis anadiplosis. Interpretasi dari kutipan tersebut adalah adanya pengulangan kata diam pada bagian akhir kalimat dan bagian awal kalimat berikutnya.

Epistrofa

Kabut turun pelan. Dingin merambat pelan. Cahaya senja susut pelan. (SLLYKDR:97)

Pada kutipan cerita dalam data (2), pengarang menggunakan gaya bahasa perulangan jenis epistrofa. Interpretasi dari kutipan tersebut adalah adanya 
pengulangan kata pelan di bagian akhir kalimat dan bagian akhir kalimat berikutnya.

Berdasarkan data hasil penelitian, diketahui bahwa terdapat gaya bahasa dalam novel Seorang Laki-Laki Yang Keluar Dari Rumah karya Puthut EA yang meliputi empat jenis dengan berbagai macam sub jenisnya, yakni : (1) gaya bahasa perbandingan meliputi: simile, metafora, antisipasi, koreksi; (2) gaya bahasa pertentangan meliputi: hiperbola, apofasisi, sarkasme, klimaks, oksimoron; (3) gaya bahasa pertautan meliputi: metonimia, erotesis, elipsis, sinekdoke, asindeton, polisindeton; (4) gaya bahasa perulangan meliputi: anafora, epizeukis, anadiplosis, epistrofa. Untuk mendapatkan informasi yang lebih jelas, perhatikan tabel 02 berikut ini.

\begin{tabular}{clc}
\hline No & Gaya Bahasa & Frekuensi Penggunaan \\
\hline 1 & Klimaks & 4 \\
\hline 2 & Sarkasme & 6 \\
\hline 3 & Asindeton & 9 \\
\hline 4 & Koreksi & 10 \\
\hline 5 & Anadiplosis & 10 \\
\hline 6 & Metafora & 11 \\
\hline 7 & Metonimia & 13 \\
\hline 8 & Oksimoron & 18 \\
\hline 9 & Hiperbola & 18 \\
\hline 10 & Epistrofa & 18 \\
\hline 11 & Antisipasi & 23 \\
\hline 12 & Anafora & 25 \\
\hline 13 & Polisindeton & 27 \\
\hline 14 & Simile & 29 \\
\hline 15 & Apofasisi & 29 \\
\hline 16 & Sinekdoke & 39 \\
\hline 17 & Epizeukis & 54 \\
\hline 18 & Erotesis & 58 \\
\hline 19 & Elipsis & 113 \\
\hline
\end{tabular}

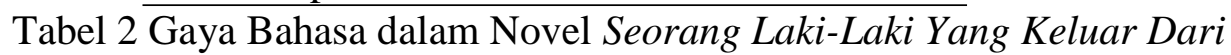
Rumah

Dari keempat jenis gaya bahasa dengan masing-masing sub jenisnya, elipsis sebagai bagian dari gaya bahasa pertautan paling banyak digunakan oleh pengarang dengan jumlah sebanyak 113 temuan dengan presentase sebesar $22 \%$ 
dari 514 data. Berbanding terbalik dengan klimaks sebagai gaya bahasa pertentangan yang paling sedikit digunakan jumlahnya hanya 4 temuan dengan presentase hanya $0,8 \%$ saja.

Penggunaan elipsis sebagai bentuk dari sebuah gaya bahasa paling banyak digunakan oleh pengarang dalam novel ini. Penggunaan gaya bahasa jenis ini sangat memengaruhi dan menuntut pembaca novel untuk menafsirkan sendiri struktur gramatikal maupun pola kalimatnya yang memang disengaja oleh pengarang tidak lengkap. Hal ini sejalan dengan pendapat Keraf (2006: 132) yang menyatakan bahwa elipsis sebagai gaya bahasa bisa ditafsirkan sendiri oleh pembaca, sehingga struktur gramatikal atau kalimatnya memenuhi pola yang berlaku dan sejalan juga dengan pendapat Ratna (2016: 440) yang menyatakan bahwa gaya bahasa jenis elipsis memiliki kalimat yang selalu tidak utuh atau tidak lengkap.

Penggunaan Citraan dalam Novel Seorang Laki-Laki Yang Keluar Dari Rumah Karya Puthut EA.

Berikut akan dianalisis citraan dalam novel Seorang Laki-Laki Yang Keluar Dari Rumah karya Puthut EA yang meliputi enam jenis meliputi citraan penglihatan, citraan pendengaran, citraan penciuman,citraan pegecepan, citraan gerak, citraan perabaan.

\section{Citraan Penglihatan}

Di rumah makan dengan cat dominan warna kuning.(SLLYKDR: 190)

Pada kutipan cerita tersebut, pengarang menggambarkan sebuah bangunan rumah dengan tembok berwarna terang melalui indera penglihatan dari tokoh cerita $A k u$. Hal tersebut terlihat pada kata rumah dan kata kuning.

Citraan Pendengaran

Bunyi hewan-hewan hutan terdengar begitu keras dalam musala ini.(SLLYKDR:208)

Pada kutipan cerita tersebut, pengarang menggambarkan suara hewan hutan melalui indera pendengaran. Hal tersebut terlihat pada kata bunyi dan kata terdengar.

Citraan Penciuman 
Bau parfum-parfum mahal menebar di ruangan. Bercampur bau kopi.(SLLYKDR:240)

Pada kutipan cerita tersebut, pengarang menggambarkan bau yang dihasilkan oleh parfum dan kopi melalui indera penciuman. Hal tersebut terlihat pada kutipan bau parfum dan bau kopi.

\section{Citraan Pengecapan}

Aku menyendok makananku. Sup yang lezat. (SLLYKDR: 234)

Pada kutipan cerita tersebut, pengarang menggambarkan makanan berupa sup melalui indera pengecapan dari tokoh Aku. Hal tersebut terlihat pada kata sup, dan kata lezat.

\section{Citraan Gerak}

Tangan kananku meninju keras mukanya sampai ada suara prak. Lakilaki itu terjungkal. (SLLYKDR: 167)

Pada kutipan cerita tersebut, pengarang menggambarkan peristiwa berupa pemukulan melalui indera gerak dari tokoh Aku. Hal tersebut terlihat pada kata meninju, dan kata terjungkal.

\section{Citraan Perabaan}

Aku mengangguk, lalu meraba buku cokelat itu di tasku dengan ragu.(SLLYKDR:255)

Pada kutipan cerita tersebut, pengarang menggambarkan indera perabaan yang dialami oleh tokoh Aku pada sebuah benda berupa buku. Hal tersebut terlihat pada kata meraba.

Berdasarkan data hasil penelitian, diketahui bahwa terdapat enam jenis citraan yang digunakan dalam novel Seorang Laki-Laki Yang Keluar Dari Rumah karya Puthut EA. Keenam jenis citraan tersebut meliputi: (1) citraan penglihatan;

(2) citraan pendengaran; (3) citraan penciuman; (4) citraan pegecepan; (5) citraan gerak; (6) citraan perabaan. Untuk mendapatkan informasi yang lebih jelas, perhatikan tabel 3 berikut ini.

\begin{tabular}{llc}
\hline No & \multicolumn{1}{c}{ Citraan } & Frekuensi Penggunaan \\
\hline 1 & Penciuman & 33 \\
\hline 2 & Perabaan & 41 \\
\hline 3 & Pengecapan & 80 \\
\hline
\end{tabular}




\begin{tabular}{lll}
\hline 4 & Pendengaran & 179 \\
\hline 5 & Gerak & 302 \\
\hline 6 & Penglihatan & 722 \\
\hline
\end{tabular}

Tabel 3Citraan dalam Novel Seorang Laki-Laki Yang Keluar Dari Rumah

Dari keenam jenis citraan tersebut, citraan penglihatan merupakan jenis citraan yang paling banyak digunakan dengan jumlah sebanyak 722 temuan dengan presentase sebesar 53,2\% dari 1357 data. Berbanding terbalik dengan citraan penciuman yang paling sedikit digunakan jumlahnya hanya 33 temuan dengan presentase hanya $2,4 \%$ saja. Citraan penglihatan digunakan dan dimanfaatkan oleh pengarang dalam menggambarkan keadaan suatu tempat, pemandangan atau bangunan. Hal ini sejalan dengan pendapat Al-Mae ruf (2010:

54) bahwa citraan penglihatan akan membangkitkan imajinasi pembacanya untuk memahami karya sastra dan perasaan estetis akan lebih mudah terangsang.Pelukisan karakter tokoh maupun keadaan fisik tokoh yang dapat dilihat oleh indera penglihat sering dikemukakan oleh pengarang melalui citraan penglihatan dalam novel ini. Hal ini juga sejalan dengan pendapat Sutejo (2010:

21) bahwa peggambaran setting dan pelukisan karakter tokoh pada hakikatnya merupakan pengalaman visual yang dialami oleh pengarang. Tanpa pengalaman visual, tetunya pengarang akan gagal dalam pelukisan pelataran secara empatif dan deskriptif.

Nilai-Nilai Pendidikan Karakter dalam Novel Seorang Laki-Laki Yang Keluar Dari Rumah Karya Puthut EA.

Berikut akan dianalisis nilai pendidikan karakter dalam novel Seorang Laki-Laki Yang Keluar Dari Rumah karya Puthut EA yang meliputi sepuluh macam meliputi nilai pendidikan karakter religius, nilai pendidikan karakter jujur, nilai pendidikan karakter toleransi, nilai pendidikan karakter disiplin, nilai pendidikan karakter gemar membaca, nilai pendidikan karakter cinta damai, nilai pendidikan karakter rasa ingin tahu, nilai pendidikan karakter bersahabat, nilai pendidikan karakter peduli sosial, nilai pendidikan karakter tanggung jawab.

Nilai Pendidikan Karakter Religius 
"Nah, pantai! Oke, nanti Bapak antar ke pantai. Kita main pasir." Aku lalu memeluknya. Membaca Al Fatihah lalu meniup telinga kanannya, membaca Al Ikhlas kemudian meniupkan telinga kirinya, dan membacakan Ayat Kursi lalu meniup ubun-ubunnya. (SLLYKDR: 238)

Pada kutipan cerita tersebut, pengarang menanamkan nilai pendidikan karakter religius dengan menggambarkan tokoh cerita menyakini ajaran agama yang dianut seperti membaca doa-doa suci dan ayat-ayat Allah.

Nilai Pendidikan Karakter Jujur

Pak Kris, satpam yang berjaga kali ini, bingung. Matanya mengeriyip seperti bangun dari tidur. Wajar, jam segini.

"Mobil yang mana, Pak?"

"Mobil yang barusan masuk, kayaknya CRV putih ..."

"Tidak ada, Pak ..."

Aku diam. Lalu mengucapkan terima kasih saat melewati portal yang sudah diangkatnya.

(SLLYKDR: 46)

Pada kutipan cerita tersebut, pengarang menanamkan nilai pendidikan karakter jujur dengan menggambarkan tokoh cerita berusaha membangun kepercayaan terhadap orang yang diajak berkomunikasi sehingga memiliki kesan tidak ada kebohongan.

\section{Nilai Pendidikan Karakter Toleransi}

Aku tetap menunggu telepon. Telepon dari sahabatku. Dan masih tidak ada. Hanya ada Rus yang, sumpah mati, orangnya lucu sekali. Juga dua temanku yang sesekali menimpali.

"Mas, aku ingin berkarya,"

"Berkarya apa?"

"Bikin film."

"Memang kamu bisa pegang kamera?"

"Nggak." 
"Lha, terus nggak bisa pegang kamera kok pengin bikin film?"

"Kan, cita-cita. Masak nggak boleh?”

Aku manggut-manggut. Mencoba mengerti. Walaupun sampai langit runtuh aku yakin tak akan bisa mengerti. (SLLYKDR: 21)

Pada kutipan cerita tersebut, pengarang menanamkan nilai pendidikan karakter toleransi dengan menggambarkan tokoh cerita memiliki sikap menghargai pendapat orang lain walaupun berbeda pendapat dari dirinya.

Nilai Pendidikan Karakter Disiplin

Pertemuan baru akan terjadi setengah jam lagi. Aku selalu lebih suka menunggu. Lebih siap dalam segala hal. Dan yang paling penting, lebih punya waktu untuk rileks. (SLLYKDR: 238)

Pada kutipan cerita tersebut, pengarang menanamkan nilai pendidikan karakter disiplin dengan menggambarkan tokoh cerita yang memiliki perilaku disiplin waktu ketika akan melakukan suatu kegiatan sehingga terhindar dari kesan mengulur waktu.

Nilai Pendidikan Karakter Gemar Membaca

Budiman sedang membaca buku, aku pikir ini sebuah kemajuan yang baik. Mungkin karena saking khusyuknya membaca, dia tidak menyadari bahwa aku sedang berada tak jauh darinya, duduk di sebuah kursi di dekatnya. (SLLYKDR: 122)

Pada kutipan cerita tersebut, pengarang menanamkan nilai pendidikan karakter gemar memabca dengan menggambarkan tokoh cerita suka terhadap buku dan memiliki niat untuk membacanya dengan sungguh-sungguh.

Nilai Pendidikan Karakter Cinta Damai

Aku menggelengkan kepala. Maksudku tidak tahu. Karena khawatir disalahartikan sebagai pembenaran bahwa Budiman tidak punya akun You Tube, aku menyatakan, "Saya tidak tahu." (SLLYKDR: 234)

Pada kutipan cerita tersebut, pengarang menanamkan nilai pendidikan karakter cinta damai dengan menggambarkan tokoh cerita memiliki sikap tidak ingin adanya konflik dengan orang lain demi terciptanya hubungan yang harmonis. 
Nilai Pendidikan Karakter Rasa Ingin Tahu

"Kuliah di mana, Dik?” tanyaku iseng kepada pemuda di sampingku yang sudah menyalakan rokok ketiganya. (SLLYKDR: 305)

Pada kutipan cerita tersebut, pengarang menanamkan nilai pendidikan karakter rasa ingin tahu dengan menggambarkan tokoh cerita memiliki rasa ingin tahu terhadap orang lain yang ditemuinya.

Nilai Pendidikan Karakter Bersahabat

Laki-laki ramping itu keluar dengan senyuman yang ramah. Kami berbagi kabar sebentar. Tidak lama kemudian dia masuk rumah. Lalu keluar lagi dengan membawa kopi dan ketela goreng. (SLLYKDR: 46)

Pada kutipan cerita tersebut, pengarang menanamkan nilai pendidikan karakter bersahabat dengan menggambarkan tokoh cerita memperlihatkan keramahan dan senang bertemu dengan orang lain.

Nilai Pendidikan Karakter Peduli Sosial

Baru selesai kontakku dengan spiritualis itu, ganti bapakku memberi kabar. Serombongan orang dari kampung datang khusus untuk berdoa di masjid rumah sakit. Setelah bapakku menutup telepon, salah seorang sahabatku di kampung menelpon. Di kampung, malam itu, para tetangga berkumpul di tiga rumah. Semua melakukan ritual doa untuk Ibu. Air mataku kembali menderas. Ibuku orang baik. Di kampung, ibuku orang yang dikenal baik. Dan kebaikannya dibuktikan lewat ratusan orang yang mendoakannya. Tanpa diminta. (SLLYKDR: 156)

Pada kutipan cerita tersebut, pengarang menanamkan nilai pendidikan karakter peduli sosial dengan menggambarkan bahwa tokoh cerita memiliki kepedulian sosial melalui kegiatan seperti doa bersama terhadap sesamanya yang sedang menderita sakit.

Nilai Pendidikan Karakter Tanggung Jawab

Siang ketika pembantaian itu terjadi, dia langsung mempersiapkan sebuah laporan panjang untuk korannya. Tapi, masih khusus untuk terbitan di daerah Timur. Dia mengirim satu wartawan ke Lumajang, berkoordinasi dengan satu wartawan yang bertugas di wilayah Jember, seorang wartawan di daerah 
Malang, tempat Tosan dirawat secara intensif, dan mengoordinir satu wartawan di Jakarta untuk memonitor tanggapan dari pemerintah pusat (SLLYKDR: 70)

Pada kutipan cerita tersebut, pengarang menanamkan nilai pendidikan karakter tanggung jawab dengan menggambarkan tokoh cerita memiliki serangkaian pekerjaan yang harus diselesaikan dan melibatkan banyak orang sehingga tanggung jawab ditanggung bersama.

Berdasarkan data hasil penelitian, dalam novel Seorang Laki-Laki Yang Keluar Dari Rumah karya Puthut EA terdapat sepuluh nilai-nilai pendidikan karakter yang sesuai dengan pedoman resmi Kemendiknas. Kesepuluh nilai pendidikan karakter dalam novel ini meliputi: (1) nilai pendidikan karakter religius; (2) nilai pendidikan karakter jujur; (3) nilai pendidikan karakter toleransi; (4) nilai pendidikan karakter disiplin; (5) nilai pendidikan karakter gemar membaca; (6) nilai pendidikan karakter cinta damai; (7) nilai pendidikan karakter rasa ingin tahu; (8) nilai pendidikan karakter bersahabat; (9) nilai pendidikan karakter peduli sosial; (10) nilai pendidikan karakter tanggung jawab. Untuk mendapatkan informasi yang lebih jelas, perhatikan tabel 4 berikut ini.

Tabel 4 Nilai Pendidikan Karakter dalam Novel Seorang Laki-Laki Yang Keluar Dari Rumah karya Puthut EA

\begin{tabular}{llc}
\hline No & Nilai Pendidikan Karakter & Frekuensi \\
\hline 1 & Disiplin & 7 \\
\hline 2 & Cinta Damai & 14 \\
\hline 3 & Peduli Sosial & 14 \\
\hline 4 & Tanggung Jawab & 15 \\
\hline 5 & Toleransi & 16 \\
\hline 6 & Jujur & 18 \\
\hline 7 & Gemar Membaca & 20 \\
\hline 8 & Religius & 22 \\
\hline 9 & Bersahabat & 35 \\
\hline 10 & Rasa Ingin Tahu & 61 \\
\hline
\end{tabular}

Dari kesepuluh nilai pendidikan karakter tersebut, nilai pendidikan karakter rasa ingin tahu yang paling banyak mendominasi sebanyak 61 temuan dengan presentase sebesar 27,5\% dari 222 temuan. Nilai pendidikan karakter rasa ingin tahu tercermin dari kepribadian para tokoh cerita yang selalu ingin 
mengetahui tentang sesuatu hal yang ditemuinya. Pengarang berusaha membuat tokoh cerita dengan memiliki rasa keingintahuan berdasarkan nalar maupun pikiran karena dengan begitu akan memudahkan pembaca dalam menafsirkan jalannya cerita. Hal ini sudah sejalan dengan Kemendiknas (2011: 9-10) yang menyatakan bahwa nilai pendidikan karakter rasa ingin tahu merupakan sikap dan tindakan yang selalu berupaya untuk mengetahui lebih mendalam dan meluas dari sesuatu yang dipelajarinya, dilihat, dan didengar.Novel dalam penelitian ini bisadigunakan dalam pembelajaran apresiasi karya sastra karena pengarang telah memanfaatkan kandungan nilai-nilai pendidikan karakter di dalam isi ceritanya. Hal ini sejalan dengan pendapat Ratna (2014: 234) yang menyatakan bahwa memanfaatkan karya sastra dalam rangka menopang pendidikan karakter berarti menghargai, melestarikan warisan nenek moyang sekaligus membatasi pengaruh budaya asing sebab segala sesuatu yang terkandung di dalamnya.

\section{SIMPULAN}

Berdasarkan pada analisis terhadap objek penelitian dengan cara mencermati dari aspek stilistika meliputi penggunaan diksi, gaya bahasa, citraan dan melakukan identifikasi terhadap nilai-nilai pendidikan karakter dalam novel Seorang Laki-Laki Yang Keluar Dari Rumah karya Puthut EA dapat ditarik sebuah simpulan. Pertama, Penggunaan kata serapan sebagai diksi paling banyak digunakan dalam novel merupakan bentuk efisien dan efektif dari segi ekspresinya, sekaligus mewakili gagasan yang ingin disampaikan pengarang kepada pembaca. Kedua, Penggunaan elipsis sebagai bentuk dari sebuah gaya bahasa paling banyak digunakan oleh pengarang dalam novel ini karena dapat memengaruhi dan menuntut pembaca novel untuk menafsirkan sendiri struktur gramatikal maupun pola kalimatnya yang memang disengaja oleh pengarang tidak lengkap.Ketiga, citraan penglihatan banyak dimanfaatkan oleh pengarang dalam menggambarkan keadaan suatu tempat, pemandangan atau bangunan.Keempat, nilai pendidikan karakter rasa ingin tahu tercermin dari kepribadian para tokoh cerita yang selalu ingin mengetahui tentang sesuatu hal yang ditemuinya. Hal tersebut, membuat pengarang berusaha membuat tokoh cerita dengan memiliki 
rasa keingintahuan berdasarkan nalar maupun pikiran karena dengan begitu akan memudahkan pembaca dalam menafsirkan jalannya cerita.

\section{DAFTAR PUSTAKA}

Al-Mae ruf, A.I. (2009). Kajian Stilistika Aspek Bahasa Figuratif Novel Ronggeng Dukuh Paruk Karya Ahmad Tohari. Kajian Linguistik dan Sastra, 21 (1), 67-80.

. (2010). Kajian Stilistika : Persepektif Kritik Holistik. Surakarta : UNS Press.

EA, Puthut. (2017). Seorang Laki-Laki Yang Keluar Dari Rumah. Yogyakarta: Mojok.

Hidayatullah, M.F. (2010). Pendidikan Karakter: Membangun Peradaban Bangsa. Surakarta: Yuma Pustaka.

Kementerian Pendidikan Nasional. (2010). Panduan Pelaksanaan Pendidikan Karakter. Jakarta: Kemendiknas.

Keraf, G. (2006). Diksi dan Gaya Bahasa. Jakarta: PT. Gramedia Pustaka Utama.

Kosasih, E. (2012). Dasar-dasar Keterampilan Bersastra. Bandung : Penerbit Yrama Widya.

Moleong, J. L. (2005). Metodologi Penelitian Kualitatif : Edisi Revisi. Bandung: PT. Remaja Rosdakarya.

Niazi, N. (2013). A Stylistic Analysis of D.H. Lawrencees „Sons and Lovers “ International Journal of Applied Linguistics \& English Literature, 2 (4), 118-126. Diperoleh pada 24 September 2017 dari http://www.journals.aiac.org.au/index.php

Nurgiyantoro, B. (2013). Teori Pengkajian Fiksi. Yogyakarta: Gadjah Mada University Press.

Pala, A. (2011). The Need For Character Education. International Journal of Social Sciences And Humanity Studies, 3 (2), 23-32. Diperoleh pada 11

Januari 2018 dari http://sobiad.org/ejournals/journal_ijss/arhieves/2011_2

Ratna, N.K. (2014). Peranan Karya Sastra, Seni dan Budaya Dalam Pendidikan Karakter. Yogyakarta: Pustaka Pelajar. . (2016). Stilistika : Kajian Puitika Bahasa, Sastra dan Budaya. Yogyakarta: Pustaka Pelajar.

Susanti, N., Abdurrahman., \& Nst, M.I. (2013). Majas Dalam Novel BidadariBidadari Surga Karya Tere Liye. Jurnal Pendidikan Bahasa dan Sastra Indonesia, 1 (2), Seri E, 356 - 362.

Sutopo, H.B. (2006). Metodologi Penelitian Kualitatif : Dasar Teori dan Terapannya dalam Penelitian. Surakarta : UNS Press.

Suwandi, S. (2013). Semantik : Pengantar Kajian Makna. Yogyakarta : Media Perkasa.

Tarigan, H.T. (2013). Pengajaran Gaya Bahasa. Bandung: Penerbit Angkasa.

Wellek, R. \& Warren, A. (2014). Teori Kesusastraan. Jakarta: PT. Gramedia Pustaka Utama. 